\title{
Semen from scrapie-infected rams does not transmit prion infection to transgenic mice
}

\author{
Pierre Sarradin, Sandrine Melo, Céline Barc, Céline Lecomte, Olivier Andréoletti ${ }^{1}$, \\ Frédéric Lantier, Jean-Louis Dacheux ${ }^{2}$ and Jean-Luc Gatti ${ }^{2}$
}

INRA, UR1282, Infectiologie Animale et Santé Publique (IASP), Nouzilly F-37380, France, ${ }^{1}$ INRA-ENVT, Interactions Hôtes-Agents Pathogènes, UMR 1225, IHAP, F-31066 Toulouse, France and ${ }^{2}$ INRA-CNRS-Haras

Nationaux-Université de Tours, UMR 6175, Physiologie de la Reproduction et des Comportements (PRC), Nouzilly F-37380, France

Correspondence should be addressed to J-L Gatti; Email: gatti@tours.inra.fr

\begin{abstract}
Scrapie is the most common transmissible spongiform encephalopathy (TSE) in livestock. Natural contamination in sheep flocks is presumed to occur by maternal transmission to offspring. However, horizontal prion transmission from animal to animal exists and may be significant in sustaining and spreading contagion in the field. Artificial insemination is widely used in modern farming, and as large amounts of prion protein have been found in sheep sperm membrane, epididymal fluid and seminal plasma, horizontal transmission by this route was hypothesized since no clear information has been obtained on possible sexual transmission of TSE. We therefore tested the contamination levels of semen from scrapie-infected rams at different stages of incubation, including the clinical phase of the disease. We report here that under our experimental conditions ram semen did not transmit infectivity to scrapie-susceptible transgenic mice overexpressing the $V^{136} R^{154} Q^{171}$ allele of the sheep prion (PRNP) gene. These results suggest that artificial insemination and natural mating have a very low or negligible potential for the transmission of scrapie in sheep flocks.

Reproduction (2008) 135 415-418
\end{abstract}

\section{Introduction}

Transmissible spongiform encephalopathies (TSEs) or prion diseases are a group of neurodegenerative conditions, which include human Creutzfeldt-Jakob disease (CJD), bovine spongiform encephalopathy (BSE) and sheep scrapie (Prusiner 2001, Aguzzi \& Miele 2004). These diseases are characterized by accumulation of an abnormal transconformed fibrillar form $\operatorname{Pr}^{\mathrm{Sc}}$ of the host prion protein $\operatorname{PrP}^{\mathrm{C}}$ in the brain. This $\mathrm{PrP}^{\mathrm{Sc}}$ is partially resistant to proteinase $\mathrm{K}$ digestion (giving rise to $\mathrm{PrP}^{\mathrm{Res}}$ ) and it has been associated with infection. However, transmission of infectivity has also been demonstrated in the absence of detectable $\operatorname{PrP}^{\text {Res }}$ in brain samples (Lasmezas et al. 1997).

Natural contamination in sheep flocks seems to occur mainly via maternal transmission to offspring, but horizontal prion transmission from animal to animal has been demonstrated and may be important in sustaining contagion (Miller \& Williams 2003, Lacroux et al. 2007). Among the horizontal routes of transmission, the oral route is strongly suspected (Andreoletti et al. 2000, Sales 2006), but other routes such as sexual transmission remain to be assessed since no clear information is available (for a critical review see Wrathall 1997).

We have previously analysed sheep semen and demonstrated that it contains high levels of normal cellular prion protein $\left(\mathrm{PrP}^{\mathrm{C}}\right)$ under different glycosylated and proteolytic isoforms, mainly derived from the epididymal fluid (Gatti et al. 2002, Ecroyd et al. 2004). $\operatorname{PrP}^{C}$ has also been found on the raft domain from the ovine sperm membrane (Gatti et al. 2002, Ecroyd et al. 2004), a result previously observed for cattle and human sperm (Shaked et al. 1999, Peoc'h et al. 2002). However, we were unable to detect PrP $P^{R e s}$ after proteinase $\mathrm{K}$ treatment of scrapie-infected ram seminal plasma (Gatti et al. 2002), suggesting the absence of $\mathrm{PrP}^{\mathrm{Sc}}$ and probably the absence of infectivity, which, however, remained to be proved. To rule out definitively any role of semen in scrapie transmission, we tested whether semen (i.e. seminal plasma and spermatozoa) could trigger the disease after inoculation to transgenic mice (tg338; overexpressing the permissive $V^{136} R^{154} Q^{171}$ allele of the ovine prion protein), one of the most sensitive tests for scrapie infection (Vilotte et al. 2001). 


\section{Results}

None of the tg338 mice injected with semen from the VRQ/VRQ genotype or from the ARR/ARR control ram showed any clinical signs during the period of the experiment (Table 1 and Fig. 1). The mice that were still alive at 749 days post-inoculation were killed because of ageing problems and their brains were removed and tested by Western blotting after proteinase $\mathrm{K}$ treatment. None of the brain suspensions from mice inoculated with semen showed any Western blot-positive reaction (Table 1).

In contrast, all tg338 mice injected with infected brain suspensions from the VRQ/VRQ and the ARQ/ARQ sheep rapidly showed clinical signs and were killed at the clinical stage of the disease between 156 and 166 days post-injection (Fig. 1). The mice brains were all tested positive for the presence of $\operatorname{PrP}^{\text {Res }}$ by Western blotting (Table 1).

\section{Discussion}

$\operatorname{PrP}^{\mathrm{Sc}}$ can accumulate in various tissues other than the nervous tissue and the transmission of TSE can be achieved by ingestion or injection of infected organ or tissue homogenates as well as by blood transfusion (Houston et al. 2000, Andreoletti et al. 2006, Thomzig et al. 2007). We have previously demonstrated that a significant amount of $\operatorname{PrP}^{\mathrm{C}}$ is present in sheep seminal plasma and epididymal fluid, but we failed to demonstrate the presence of $\mathrm{PrP}^{\mathrm{Res}}$ after immunoprecipitation of the PrP from seminal plasma obtained from scrapieinfected animals (Gatti et al. 2002). It was, however, important to examine whether sheep semen could be infectious as the absence of $\mathrm{PrP}^{\text {Res }}$ does not always mean the absence of infectivity (Lasmezas et al. 1997). To achieve this, we used a genetically modified mouse line that overexpresses the sheep VRQ allele and is considered to be highly effective in the detection of scrapie infectivity, demonstrated by the short incubation period observed after inoculation of brain homogenates from infected VRQ/VRQ or VRQ/ARQ sheep from the same flock (Telling et al. 1995, Vilotte et al. 2001). The $\operatorname{tg} 338$ mouse line has been proved to be able to detect infectivity in a tissue with less than $1 / 5000$ brain infectivity, which is equivalent to sensitivity within the picogram range of $\operatorname{Prp}^{\text {sc }}$ per milligram of tissue (Andreoletti et al. 2004). Our results demonstrated that the transmission of scrapie did not occur with semen from infected rams at any point during scrapie incubation, even with a highly infected animal such as the oldest VRQ/VRQ ram that was sampled at the clinical stage and when spermatozoa and seminal plasma (and also cells and organelles that can be found within this fluid (Gatti et al. 2005, Sutovsky et al. 2007)) contain undetectable levels of infectivity. This absence of infectivity in sheep semen may reflect the lack of transconformation of the prion protein in the genital tract due to either the specific biochemical properties of the different glycosylated and truncated forms present (Shaked et al. 1999, Ecroyd et al. 2005) or the high level of protection formed by the testicular and epididymal blood barrier (Cyr et al. 2007). It could also be hypothesized that these tissues lack one or more (still unidentified) cofactors needed for the efficient conversion of $\mathrm{PrP}^{\mathrm{C}}$ to $\mathrm{PrP}^{\mathrm{SC}}$ (Telling et al. 1995, Marc et al. 2007).

In order to match as closely as possible what happens in the field, semen was collected and treated as for insemination in this study. Only $20 \mu \mathrm{l}$ raw semen could be injected into the brain of each mouse but they contained a quarter of the cells and seminal plasma of semen used for artificial insemination (AI) in sheep $\left(4 \times 10^{8}\right.$ spermatozoa per $\left.\mathrm{Al}\right)$, and more than five times the quantity used for bovine insemination $\left(20 \times 10^{6}\right.$ spermatozoa per $\mathrm{Al}$ ). Because ewes are only mated or inseminated a few times in their lives (between 5 and 10 times), we can confidently conclude that the semen used in artificial insemination is an unlikely vector for scrapie transmission in sheep, although our results would need to be confirmed with a larger number of infected rams or by injection of a larger volume of semen to mice by the

Table 1 Results of inoculation of tg338 mice with extracts of scrapie brain and semen.

\begin{tabular}{|c|c|c|c|c|c|c|}
\hline \multirow[b]{3}{*}{ Number } & \multicolumn{4}{|c|}{ Donor sheep } & \multicolumn{2}{|c|}{$\operatorname{tg} 338$ mice } \\
\hline & \multirow[b]{2}{*}{ Genotype } & \multirow[b]{2}{*}{ Tissue } & \multicolumn{2}{|c|}{ Age (months) at } & \multirow{2}{*}{$\begin{array}{l}\text { Days to terminal } \\
\qquad\left(n / n_{0}\right)^{\mathrm{a}}\end{array}$} & \multirow{2}{*}{$\begin{array}{l}\text { Confirmed } \\
\text { diagnosis }^{b}\end{array}$} \\
\hline & & & Sampling & Death $^{c}$ & & \\
\hline 1 & VRQ/VRQ & Brain & 24 & 24 & $157(5 / 5)$ & + \\
\hline 2 & VRQ/VRQ & Brain & 24 & 24 & $155(6 / 6)$ & + \\
\hline 3 & $\mathrm{ARQ} / \mathrm{ARQ}$ & Brain & 24 & 24 & $166(6 / 6)$ & + \\
\hline 4 & ARQ/ARQ & Brain & 24 & 24 & $165(6 / 6)$ & + \\
\hline 5 & VRQ/VRQ & Semen & $24^{\mathrm{d}}$ & 25 & $>749(0 / 14)$ & - \\
\hline 6 & VRQ/VRQ & Semen & 14 & 21 & $>749(0 / 13)$ & - \\
\hline 7 & VRQ/VRQ & Semen & 8 & 21 & $>749(0 / 13)$ & - \\
\hline 8 & ARR/ARR & Semen & 58 & 90 & $>749(0 / 15)$ & - \\
\hline
\end{tabular}

${ }^{\mathrm{a}}$ Mean value for all animals in the set (number of diseased animals/number of animals inoculated). ${ }^{\mathrm{b}}$ Results of Western blotting performed on mouse brains. ${ }^{\mathrm{C}}$ All animals killed at the terminal stage of the disease, except sheep \#8. ${ }^{\mathrm{d}}$ Sheep \#5 showed clinical signs at time of sampling. 


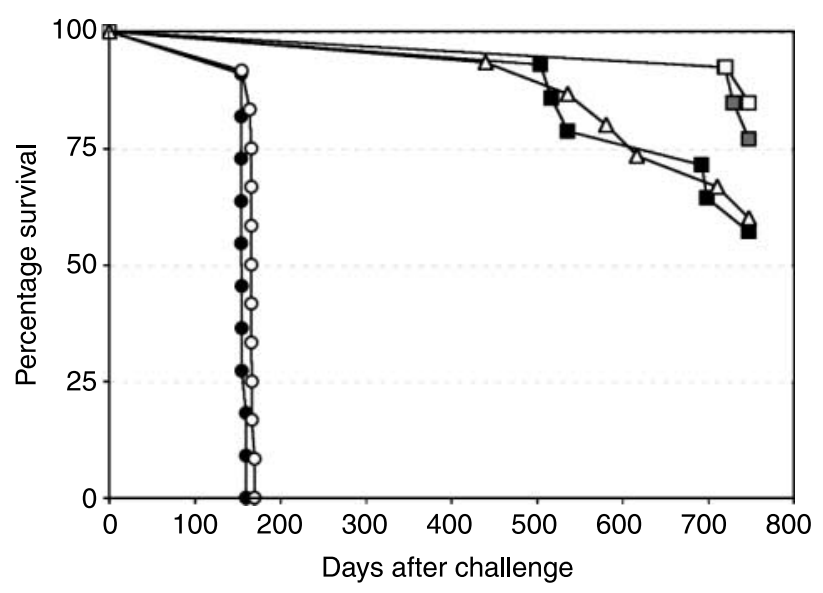

Figure 1 Survival curves of mice injected with brain extracts and semen from scrapie-infected sheep. Fourteen 9-week-old transgenic mice ( $\operatorname{tg} 338)$ were injected intracerebrally with either brain homogenates (0.2 mg brain equivalent per mouse) from scrapie-infected VRQ (filled circle) or ARQ (open circle; mean of two different experiments with two different sheep for each genotype) or with $20 \mu \mathrm{l}$ semen from an ARR ram (triangle) and VRQ-infected rams of different ages (8 months, white square; 14 months, grey square; 24 months, black square). No statistical differences were observed in survival curves between groups of mice inoculated with semen from either susceptible or resistant sheep (Kaplan-Meier $\chi^{2}=2.313$, d.f. $=3, P=0.51$ ).

i.p. route, although this could be a less sensitive test than the intracerebral route.

Our results are important because millions of artificial inseminations are performed each year in sheep and various other species (Thibier 2005), and it is a widespread practice that has commercial and economical impact in the modern agriculture and also for the human reproduction.

\section{Materials and Methods \\ Biological materials}

Semen was obtained from adult Romanov rams and brain samples from adult Romanov sheep. All animals were born and raised in the chronically infected INRA Langlade experimental flock (Elsen et al. 1999). For semen, rams from two PrP genotypes were used: three scrapie-susceptible VRQ/VRQ rams $(8,14$ and 24 months old) and one scrapie-resistant ARR/ ARR ram (58 months old). In this flock, VRQ/VRQ rams are used for reproduction and fertility for the different sensitive genotypes is about $60 \%$ vs $72 \%$ for resistant genotypes. The 24-month-old VRQ/VRQ ram already showed classical signs of infection (weight loss, head tremor, scratching, etc.). The other two did not show any signs at the time of collection but developed symptoms later. For brain, 24-month-old VRQ/VRQ and VRQ/ARQ sheep (both sensitive genotypes of the same breed and reared in the same flock at the same time) were used. All VRQ/VRQ and VRQ/ARQ animals were killed at the clinical stage and their brains were found to be positive for scrapie by immunohistochemistry (not shown).

Given the well-documented time-course of the disease in VRQ/VRQ sheep in this experimental flock, the positive result indicated that the younger rams were already contaminated at the time of semen collection (Andreoletti et al. 2000). As expected, the ARR/ARR ram did not show any clinical signs but was killed at 90 months of age and its brain was found to be negative for scrapie. One ejaculate was collected from each ram by artificial vagina and rapidly frozen at $-20^{\circ} \mathrm{C}$. After defrosting, ejaculates were tested for bacterial contamination before injection and mixed with an antibiotic cocktail (penicillin $2 \mu \mathrm{g}$; streptomycin $2 \mu \mathrm{g}$; kanamycin $2 \mu \mathrm{g}$ per injection) that did not interfere with scrapie transmission.

\section{Mouse bioassay}

For each crude semen sample, $20 \mu \mathrm{l}$ containing about $10^{8}$ sperm cells were injected intracerebrally under anaesthesia to fourteen 9-week-old tg338 mice. As an infectivity control, $20 \mu \mathrm{l}$ brain suspensions $(10 \mathrm{mg} / \mathrm{ml})$ from the infected VRQ/VRQ and the VRQ/ARQ sheep were injected intracerebrally to five or six tg338 mice (experiment performed twice).

Mice were then monitored each day for clinical signs, and either killed at the terminal stage of the disease or killed after 749 days. Any death arising during the experimental period was recorded and all mice, including those that died from intercurrent diseases, were necropsied for brain sampling. A $10 \%(\mathrm{w} / \mathrm{v})$ solution was made for all brains, treated with proteinase $\mathrm{K}$ and tested for $\mathrm{PrP}^{\mathrm{Res}}$ by Western blotting using the mouse monoclonal antibody 8G8 (Krasemann et al. 1999).

All animals were killed according to the requirements of the INRA Animal Care and Ethics Committee.

\section{Acknowledgements}

This study was supported by national grants from Groupement d'Intérêt Scientifique Prion and by the Région Centre. We thank Dr Carole Moreno-Romieux for confirmation of the scrapie status of the rams (INRA SAGA, Castanet-Tolosan) and the staff of the Domaine de Langlade (INRA, Pompertuzat) and of the Animalerie Rongeurs (INRA PFIE Tours-Nouzilly).The authors declare that there is no conflict of interest that would prejudice the impartiality of this scientific work.

\section{References}

Aguzzi A \& Miele G 2004 Recent advances in prion biology. Current Opinion in Neurology 17 337-342.

Andreoletti O, Berthon P, Marc D, Sarradin P, Grosclaude J, van Keulen L, Schelcher F, Elsen JM \& Lantier F 2000 Early accumulation of $\operatorname{PrP}(\mathrm{SC})$ in gut-associated lymphoid and nervous tissues of susceptible sheep from a Romanov flock with natural scrapie. Journal of General Virology $\mathbf{8 1}$ 3115-3126.

Andreoletti O, Simon S, Lacroux C, Morel N, Tabouret G, Chabert A, Lugan S, Corbiere F, Ferre P, Foucras G et al. 2004 PrPSc accumulation in myocytes from sheep incubating natural scrapie. Nature Medicine $\mathbf{1 0}$ 591-593. 
Andreoletti O, Morel N, Lacroux C, Rouillon V, Barc C, Tabouret G, Sarradin P, Berthon P, Bernardet P, Mathey J et al. 2006 Bovine spongiform encephalopathy agent in spleen from an ARR/ARR orally exposed sheep. Journal of General Virology 87 1043-1046.

Cyr DG, Gregory M, Dube E, Dufresne J, Chan PT \& Hermo L 2007 Orchestration of occludins, claudins, catenins and cadherins as players involved in maintenance of the blood-epididymal barrier in animals and humans. Asian Journal of Andrology 9 463-475.

Ecroyd H, Sarradin P, Dacheux JL \& Gatti JL 2004 Compartmentalization of prion isoforms within the reproductive tract of the ram. Biology of Reproduction 71 993-1001.

Ecroyd H, Belghazi M, Dacheux JL \& Gatti JL 2005 The epididymal soluble prion protein forms a high molecular weight complex in association with hydrophobic proteins. The Biochemical Journal 392 211-219.

Elsen JM, Amigues $Y$, Schelcher F, Ducrocq V, Andreoletti O, Eychenne F, Khang JV, Poivey JP, Lantier F \& Laplanche JL 1999 Genetic susceptibility and transmission factors in scrapie: detailed analysis of an epidemic in a closed flock of Romanov. Archives of Virology 144 431-445.

Gatti JL, Metayer S, Moudjou M, Andreoletti O, Lantier F, Dacheux JL \& Sarradin P 2002 Prion protein is secreted in soluble forms in the epididymal fluid and proteolytically processed and transported in seminal plasma. Biology of Reproduction 67 393-400.

Gatti JL, Metayer S, Belghazi M, Dacheux F \& Dacheux JL 2005 Identification, proteomic profiling, and origin of ram epididymal fluid exosome-like vesicles. Biology of Reproduction 72 1452-1465.

Houston F, Foster JD, Chong A, Hunter N \& Bostock CJ 2000 Transmission of BSE by blood transfusion in sheep. Lancet 356 999-1000.

Krasemann S, Jurgens T \& Bodemer W 1999 Generation of monoclonal antibodies against prion proteins with an unconventional nucleic acidbased immunization strategy. Journal of Biotechnology 73 119-129.

Lacroux C, Corbiere F, Tabouret G, Lugan S, Costes P, Mathey J, Delmas JM, Weisbecker JL, Foucras G, Cassard H et al. 2007 Dynamics and genetics of PrPSc placental accumulation in sheep. Journal of General Virology $\mathbf{8 8}$ 1056-1061.

Lasmezas CI, Deslys JP, Robain O, Jaegly A, Beringue V, Peyrin JM, Fournier JG, Hauw JJ, Rossier J \& Dormont D 1997 Transmission of the BSE agent to mice in the absence of detectable abnormal prion protein. Science 275 402-405.

Marc D, Mercey R \& Lantier F 2007 Scavenger, transducer, RNA chaperone? What ligands of the prion protein teach us about its function Cellular and Molecular Life Sciences 64 815-829.
Miller MW \& Williams ES 2003 Prion disease: horizontal prion transmission in mule deer. Nature 425 35-36.

Peoc'h K, Serres C, Frobert Y, Martin C, Lehmann S, Chasseigneaux S, Sazdovitch V, Grassi J, Jouannet P, Launay JM et al. 2002 The human 'prion-like' protein Doppel is expressed in both Sertoli cells and spermatozoa. Journal of Biological Chemistry 277 43071-43078.

Prusiner SB 2001 Shattuck lecture-neurodegenerative diseases and prions. New England Journal of Medicine 344 1516-1526.

Sales $\mathbf{N} 2006$ What can we learn from the oral intake of prions by sheep? Journal of Pathology 209 1-3.

Shaked Y, Rosenmann H, Talmor G \& Gabizon R 1999 A C-terminaltruncated PrP isoform is present in mature sperm. Journal of Biological Chemistry 274 32153-32158.

Sutovsky P, Plummer W, Baska K, Peterman K, Diehl JR \& Sutovsky M 2007 Relative levels of semen platelet activating factor-receptor (PAFr) and ubiquitin in yearling bulls with high content of semen white blood cells: implications for breeding soundness evaluation. Journal of Andrology $\mathbf{2 8}$ 92-108.

Telling GC, Scott M, Mastrianni J, Gabizon R, Torchia M, Cohen FE, DeArmond SJ \& Prusiner SB 1995 Prion propagation in mice expressing human and chimeric PrP transgenes implicates the interaction of cellular PrP with another protein. Cell 83 79-90.

Thibier M 2005 The zootechnical applications of biotechnology in animal reproduction: current methods and perspectives. Reproduction, Nutrition, Development 45 235-242.

Thomzig A, Schulz-Schaeffer W, Wrede A, Wemheuer W, Brenig B, Kratzel C, Lemmer K \& Beekes M 2007 Accumulation of pathological prion protein PrPSc in the skin of animals with experimental and natural scrapie. PLoS Pathogens 3 e66.

Vilotte JL, Soulier S, Essalmani R, Stinnakre MG, Vaiman D, Lepourry L, Da Silva JC, Besnard N, Dawson M, Buschmann A et al. 2001 Markedly increased susceptibility to natural sheep scrapie of transgenic mice expressing ovine prp. Journal of Virology 75 5977-5984.

Wrathall AE 1997 Risks of transmitting scrapie and bovine spongiform encephalopathy by semen and embryos. Revue Scientifique et Technique 16 240-264.

Received 27 August 2007

First decision 24 September 2007

Accepted 27 November 2007 